\title{
Suitability Evaluation of River Owan Water for Irrigation
}

\author{
Abel O. Talabi, Lekan O. Afolagboye, Adeyinka O. \\ Aturamu and Sylvester W. Olofinlade \\ Department of Geology, Ekiti State University, Ado-Ekiti, Nigeria
}

\begin{abstract}
Water samples from River Owan located within the Benin-Owena River Basin, southwestern Nigeria, were investigated for irrigation suitability employing electrical conductivity (EC), Sodium Absorption Ratio (SAR), \%Na, Residual Sodium Bicarbonate (RSBC), Potential Salinity (PS), Soluble Sodium Product (SSP), Magnesium absorption ratio (MAR), Kelly ratio (KR) and Wilcox plot. Estimated irrigation parameters revealed that SAR ranged from $0.15-1.4$ (av. 0.33), RSBC; -1.75 - 2.68 (av.0.73), MAR; $36.86-77.41$ (av. 60.11), KR; $1.69-8.37$ (av. 3.06) while PS, SSP and \%Na were from 0.01 - 3.12 (av. 0.56), $31.51-70.33$ (av. 55.99) and 19.93 - 58.69 (av55.99) respectively. Furthermore, Wilcox plot revealed that all water samples from River Owan were in the excellent to good irrigation category. All estimated indices except MAR and KR indicated that River Owan water was suitable for irrigation. Wells at Owan were shallow and pruned to dryness during dry season. River Owan water that was moderately suitable for irrigation could serve as a buffer to farming activities especially during dry season.
\end{abstract}

Keywords: electrical conductivity, farming activities, Wilcox plot, wells, irrigation parameter.

\section{Introduction}

Water is the most important input required for plant growth for agricultural production. Nigeria is endowed with abundant surface water resources estimated to be about 267 billion $\mathrm{m}^{3}$ /annum [1]. Despite the abundance water resources, agricultural activities have suffered serious setback because of climatic variability as well as uneven distribution of the resources. The dry season is usually a challenging period for farmers because of low precipitation resulting into inability to decide when and what to plant. Farmers face unpredictable weather brought on by climate change. Sometimes the rainy season comes late; at other times, it ends early. Sometimes the rains come late and hard, causing floods. At other times, rains don't come at all, causing drought. With these weather changes, it is difficult for farmers to plan which crops to grow, when to prepare land, when to plant and how to plan other farming tasks. Worst hit are those farmers from the Northern part of the country who have to respond to serious weather changes, making it difficult for them to farm during dry season (October to May) that has prolonged periods in the North compared to southern areas of the country (November to March). The weather during this period is much hotter and drier. For this reason, farmers adopt various agricultural practices to confront these differences in weather patterns. Irrigation that entails replenishment of soil water storage in plant root zone through methods other than natural precipitation has been adopted to combat variability in climate in many parts of the country. River Owan in the Benin-Owena River Basin, southwestern Nigeria flows throughout the year though with reduced volume in the dry season.

Available literature on environmental monitoring of surface water indicated that streams and rivers in Nigeria are showing increasing trend of water pollution due to increase population, industrialization and urbanization. Waste generations by the industries and households have continued to increase. These wastes were indiscriminately disposed-off into the water bodies which have led to pollution of inland water bodies and coastal waters. Subsequently, water quality parameters such as heavy metals, nutrients and organic matter, soluble ions, oil and grease and organic chemicals such as pesticides and poly-nuclear aromatic hydrocarbons (PAHs), have increased $[2,3,4,5,6]$. Urgent attention is therefore necessary to mitigate water pollution problems which are not limited to drinking quality alone but also irrigation and industrial qualities. Waste management is a major problem in most developing nations of the world including Nigeria [7]. Indiscriminate disposal of municipal wastes remains a major threat to surface water pollution in Nigeria. In most cases, sewage and waste water from homes are routed into the rivers and streams. [4] found elevated water quality parameters in some sampling locations of Ogun River. These were partly attributed to the activities of abattoir located close to the River at a notable market in Abeokuta metropolis. The work of [8] on the impact of sawmill activities on the water quality of a river in Benin reported high BOD and low DO values at the discharge point of the wastes into the River.

The impact of point source pollution from sewage treatment on a receiving stream was studied by [9]. The researchers observed significant elevation of water indices such as $\mathrm{pH}, \mathrm{BOD}$, nitrate, phosphate and total soluble salt (TSS). Research work of [10] on effects of climate change on irrigation activities: a case study of the Benin-Owena River basin irrigation projects revealed that climate records showed a large variation in annual 
rainfall between 1961-1980.The rainfall variation between1980-2000 was less pronounced, and rainfall was much lower. The period 1982-1986 exhibited the greatest downward trend in rainfall.

Irrigated agriculture is dependent on an adequate water supply of usable quality. In irrigation water evaluation, emphasis is placed on the chemical and physical characteristics of the water and only rarely is any other factors considered important. The quality and quantity of the source of water can have a significant impact on the irrigation. In this study, attempt has been made to assess the irrigation water quality of river Owan in the Benin-Owena River Basin, southwestern Nigeria laying emphasis on Total dissolved solids (TDS), Electrical conductivity (EC) Magnesium absorption ratio(MAR), sodium percentage (SP), Sodium adsorption ratio (SAR), Residual sodium carbonate (RSC) and Permeability index (PI).

\section{Location And Geology}

River Owan water within Benin-Owena River Basin, southwestern Nigeria has been selected for this study (Fig. 1). The area lies within $6^{\circ} 45^{\prime}$ and $6^{\circ} 45.3^{\prime} \mathrm{N}$ Latitudes, $5^{\circ} 45^{\prime}$ and $5^{\circ} 47.5^{\prime}$ E Longitudes. The study area is characterized by two distinct seasons, namely, the wet and dry seasons. The wet season occurs between April and October with a break in August and average rainfall which ranges from $1800 \mathrm{~mm}-2500 \mathrm{~mm}$, while the dry season last from November to April. The harmattan season is experienced between December and January. The vegetation of the study area varies from swamp forest to rain forest.

\section{Methodology}

Data for this study was extracted from the research of [11] on Hydrochemistry and Environmental Status of River Owan water, Edo State Nigeria (International Journal of Environment and Pollution Research Vol.4, No.5, pp. 1-15). The data comprised of 12 river Owan water samples that have been subjected to hydrochemical analysis following standard method [12]. Chemical concentrations from the data were extracted and needed irrigation indices estimated for the following parameters;

The Sodium Adsorption Ratio (SAR) was calculated using the equation of [13]:

$\mathrm{SAR}=\mathrm{Na}^{+} / \sqrt{\left(\mathrm{Ca}^{2+}+\mathrm{Mg}^{2+}\right)}$

2

(All the ions are expressed in meq/l)

The Residual Sodium Bicarbonate (RSBC) was calculated according to [14];

$\mathrm{RSBC}=\mathrm{HCO}_{3}^{-}-\mathrm{Ca}^{2+}$

(All the ions are expressed in meq/l)

The Magnesium Adsorption Ratio was calculated using the following equation [15]:

$\mathrm{MAR}=\underline{\mathrm{Mg}^{2+} * 100}$

$\left(\mathrm{Ca}^{2+}+\mathrm{Mg}^{2+}\right)$

(All the ions are expressed in meq/l)

The Kelly Ratio (KR) was given by [16]:

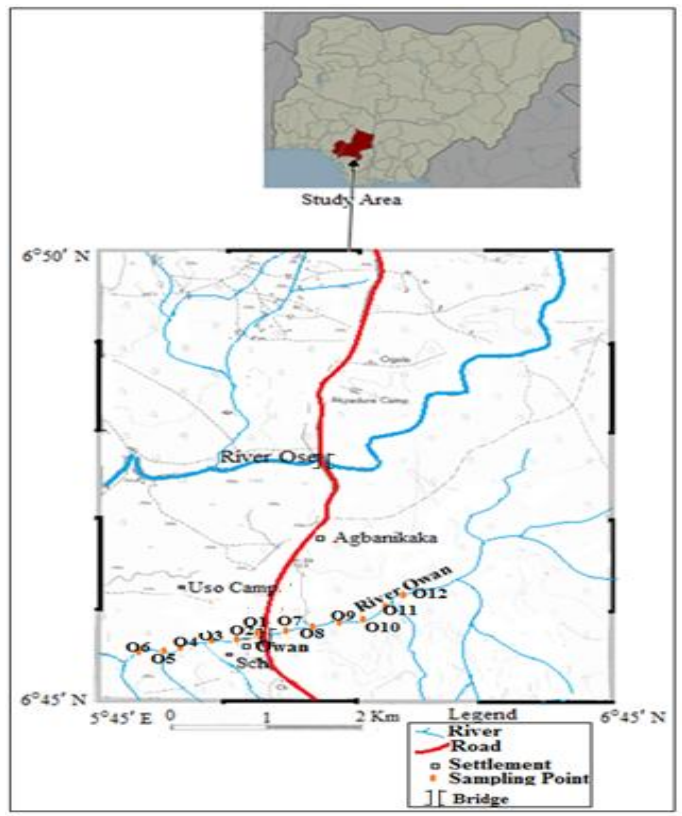

Figure 1. Location of Study 
$\mathrm{KR}=\mathrm{Na}+/\left(\mathrm{Ca}^{2+}+\mathrm{Mg}^{2+}\right)$

(All the ions are expressed in meq/l)

The Potential Salinity (PS) was calculated according to [17] by the formula:

$\mathrm{PS}=\mathrm{Cl}^{-} 0.5 * \mathrm{SO}_{4}$

(All the ions are expressed in meq/l)

The Soluble Sodium Percentage (SSP) was carried out by the following equation:

$\mathrm{SSP}=\left(\left(\mathrm{Na}^{+}+\mathrm{K}^{+}\right) /\left(\mathrm{Ca}^{2+}+\mathrm{Mg}^{2+}+\mathrm{Na}^{+}+\mathrm{K}^{+}\right)\right) * 100$

(All the ions are expressed in meq/l)

Permeability Index (PI) was calculated employing the equation of [17]

$$
\mathrm{PI}=\frac{\mathrm{Na}^{+}+\sqrt{ }\left(\mathrm{HCO}_{3}^{-} \times 100\right)}{\mathrm{Ca}^{2+}+\mathrm{Mg}^{2+}+\mathrm{Na}^{+}}
$$

Apart from the listed parameters, Wilcox plot was obtained by plotting \%Na versus EC [18] while United State Salinity Laboratory (USSL) irrigation quality diagram was obtained by plotting SAR versus EC [19].

\section{Results And Discussion}

The results of the various physical and chemical parameters of water samples from the study area are presented in TABLES 1 and 2 respectively. Details of the hydrochemistry of the area have been discussed in [11]. However, estimated irrigation parameters (TABLE 3) revealed that SAR ranged from 0.15 - 0.39 (av. 0.19), RSBC; 0.55 - 2.68 (av.1.06), MAR; 36.86 - 65.08 (av. 59.28), KR; 1.69 - 2.49 (av. 2.20) while PS, SSP, $\% \mathrm{Na}$, Revelle Index and PI ranged from 0.01 - 1.34 (av. 0.27), 47.05 - 70.33 (av. 58.13), 19.93 - 38.03 (av. 33.33), $0.34-0.98$ (av. 0.53) and 5.90 - 46.64 (av. 31.07) respectively. Classification of groundwater for irrigation based on EC, SAR is presented in TABLE 4 while the summary of irrigation quality characteristics of River Owan water is presented in TABLE 5. Furthermore, Wilcox plot revealed that all water samples from River Owan fell into the excellent to good irrigation category.

Salinity and indices such as sodium absorption ratio (SAR), sodium percentage (Na \%), residual sodium Bicarbonate (RSBC), Kelly Ratio (KR) and Magnesium adsorption ratio (MAR) are important parameters for determining the suitability of water for agricultural uses [20]. Electrical conductivity is a good measure of salinity hazard to crops as it reflects the TDS in groundwater. The water salinity hazard measured employing EC constitutes the most influential water quality guideline on crop productivity [21]. The primary effect of high EC water on crop productivity is the inability of the plants to compete with ions in the soil solution for water (physiological drought). The higher the EC, the less water is available to plants, even though the soil may appear wet. Because plants can only transpire "pure" water, usable plant water in the soil solution decreases dramatically as EC increases. Water with $\mathrm{EC}<250 \mu \mathrm{S} / \mathrm{cm}$ is considered good and that with EC $>750$ $\mu \mathrm{S} / \mathrm{cm}[22]$ is unsuitable for irrigation. Based on this submission, the River Owan water is suitable for irrigation. In addition employing the US Salinity Laboratory [19] classification of groundwater on the basis of electrical conductivity (TABLE 4), 11 samples (92\%) of the River Owan water were excellent for irrigation while 1 sample $(8 \%)$ fell into the good irrigation category.

The SAR values ranged from 0.15 to 0.39 and the water from the study area fell into the excellent irrigation quality category [13]. The degree of cation-exchange reactions in soil can be indicated by SAR of irrigation water as high SAR is indicative of excess $\mathrm{Na}^{+}$ions in the soil that can replace $\mathrm{Ca}^{2+}$ and $\mathrm{Mg}^{2+}$ through cations exchange processes. Soils structure is damaged when $\mathrm{Na}^{+}$replaces $\mathrm{Ca}^{2+}$ and $\mathrm{Mg}^{2+}$. The soil is compacted and becomes indurated/impervious [23]. Furthermore, the \%Na plotted against EC [18] revealed that the River Owan water is also in the excellent irrigation quality category (Fig. 7). Values of all \% Na of water in the study area are less than $60 \%$. Irrigation water with $\% \mathrm{Na}>60 \%$ may result in sodium accumulation and possibly deterioration of soil structure, infiltration and aeration [24].

Table 1. Physical Parameters of Water Samples from the Study Area

\begin{tabular}{|l|l|l|l|l|l|}
\hline Code & Temp. & $\mathbf{p H}$ & $\mathbf{E C}(\square \square / \mathbf{c m})$ & TDS $(\mathbf{m g} / \mathbf{l})$ & $\mathbf{T H}(\mathbf{m g} / \mathbf{L})$ \\
\hline O1 & 27.6 & 11.3 & 69 & 51.75 & 12.08 \\
\hline O2 & 27.8 & 10.6 & 45 & 33.75 & 6.61 \\
\hline O3 & 26.9 & 10.2 & 45 & 33.75 & 6.46 \\
\hline O4 & 27.2 & 9.5 & 48 & 36 & 6.61 \\
\hline O5 & 27.1 & 9.2 & 58 & 43.5 & 7.08 \\
\hline
\end{tabular}




\begin{tabular}{|l|l|l|l|l|l|}
\hline O6 & 27.8 & 9 & 47 & 35.25 & 6.48 \\
\hline O7 & 28.3 & 8.6 & 533 & 399.75 & 120.05 \\
\hline O8 & 27.4 & 9.2 & 64 & 48 & 17.54 \\
\hline O9 & 27.1 & 9.1 & 46 & 34.5 & 6.57 \\
\hline O10 & 27.3 & 8.9 & 67 & 50.25 & 9.78 \\
\hline O11 & 27.4 & 8.8 & 76 & 57 & 10.63 \\
\hline O12 & 27.4 & 8.8 & 45 & 33.75 & 7.19 \\
\hline Min & 26.90 & 8.60 & 45.00 & 33.75 & 6.46 \\
\hline Max & 28.30 & 11.30 & 533.00 & 399.75 & 120.05 \\
\hline Mean & 27.44 & 9.43 & 95.25 & 71.44 & 18.09 \\
\hline Stdev & 0.38 & 0.83 & 138.30 & 103.73 & 32.28 \\
\hline $\begin{array}{l}\text { WHO } \\
\text { (2006) }\end{array}$ & - & 6.5 & 1000 & $600-1000$ & $200-500$ \\
\hline
\end{tabular}

Hazardous effect of bicarbonate on the quality of water for agricultural purpose is assessed using residual sodium bicarbonate (RSBC). RSBC $>2.5 \mathrm{meq} / \mathrm{L}$ is not suitable for irrigation [14]. In this research all RSBC values are less than $2.5 \mathrm{meq} / \mathrm{L}$ except in one location with value $(2.68)>2.5$. River Owan water is therefore suitable for irrigation. Persistent use of water having RSBC $>2.5 \mathrm{meq} / \mathrm{l}$ results to salt build up which hardened soils $[25,26]$.

Other irrigation parameters employed in this research include, Potential Salinity (PS), Permeability Index (PI) and Soluble Sodium Percentage (SSP) revealed that River Owan water is suitable for irrigation while Kelly Ratio (KR) and Magnesium adsorption Ratio (MAR) indicated otherwise. The soil permeability is influenced by long term use of irrigation water and sodium, calcium, magnesium, bicarbonate content of the soil [23]. [17], evolved a criterion for assessing the suitability of water for irrigation based on the permeability index. Accordingly, waters can be classified as class I, Class II and Class III orders. Class I and Class II waters are categorized as good for irrigation with $75 \%$ or more maximum permeability. Class III water are unsuitable with $25 \%$ of maximum permeability. In the present study, the permeability index values ranged from $5.90-$ $46.64 \%$. Specifically, 3 (25\%) samples have PI, $25 \%$ while the remaining 9 (75\%) samples have $75 \%>$ PI> $25 \%$. Thus majority of the samples fell into Class II of Doneen classification and River Owan water is suitable for irrigation based on PI assessment. According to [17], water with PS $<3 \mathrm{meq} / \mathrm{L}$ is suitable for irrigation purposes. In this study, the River Owan water has PS values that are generally less than 1.5. Thus, based on PS, River Owan water is very good for irrigation purposes.

Table 2. Result of Chemical Parameters of Water Samples from the Study Area

\begin{tabular}{|c|c|c|c|c|c|c|c|c|}
\hline Code & $\begin{array}{l}\mathrm{Ca}^{2+} \\
(\mathrm{mg} / \mathrm{L})\end{array}$ & $\begin{array}{l}\mathrm{Mg}^{2+} \\
(\mathrm{mg} / \mathrm{L})\end{array}$ & $\begin{array}{l}\mathrm{Na}^{+} \\
(\mathrm{mg} / \mathrm{L})\end{array}$ & $\mathrm{K}^{+}(\mathrm{mg} / \mathrm{L})$ & $\begin{array}{l}\mathrm{HCO}_{3}{ }^{-} \\
(\mathrm{mg} / \mathrm{L})\end{array}$ & $\begin{array}{l}\mathrm{SO}_{4}{ }^{2-} \\
(\mathrm{mg} / \mathrm{L})\end{array}$ & $\begin{array}{l}\mathrm{Cl}^{-} \\
(\mathrm{mg} / \mathrm{L})\end{array}$ & $\begin{array}{l}\mathrm{NO}_{3}{ }^{-} \\
(\mathrm{mg} / \mathrm{L})\end{array}$ \\
\hline $\mathrm{O} 1$ & 2.23 & 1.56 & 4.23 & 8.82 & 85.4 & 0.86 & 43.2 & 0.47 \\
\hline $\mathrm{O} 2$ & 1.01 & 0.98 & 2.45 & 2.34 & 61 & 7.76 & 21.6 & 4.06 \\
\hline O3 & 1 & 0.95 & 2.42 & 2.2 & 36.6 & 9.05 & 36 & 6.43 \\
\hline $\mathrm{O} 4$ & 1.01 & 0.98 & 2.63 & 3.01 & 61 & 21.34 & 36 & 2.18 \\
\hline O5 & 1.1 & 1.04 & 2.81 & 4.23 & 60.4 & 25.65 & 28.8 & 6.76 \\
\hline O6 & 0.94 & 0.99 & 2.6 & 2.34 & 61 & 28.23 & 28.8 & 4.14 \\
\hline O7 & 30.32 & 10.62 & 28.11 & 35.53 & 256.2 & 44.61 & 100.8 & 2.75 \\
\hline O8 & 2.45 & 2.74 & 5.42 & 23.24 & 61 & 29.96 & 21 & 4.47 \\
\hline O9 & 1.01 & 0.97 & 2.78 & 2.56 & 85.4 & 33.19 & 36 & 3.32 \\
\hline O10 & 1.53 & 1.43 & 3.64 & 4.33 & 48.8 & 25.86 & 28.8 & 4.31 \\
\hline O11 & 1.62 & 1.58 & 4.11 & 3.34 & 48.8 & 7.33 & 28.8 & 7.08 \\
\hline O12 & 1.11 & 1.06 & 2.83 & 2.23 & 48.8 & 18.32 & 28.8 & 6.76 \\
\hline Min & 0.94 & 0.95 & 2.42 & 2.20 & 36.60 & 0.86 & 21.00 & 0.47 \\
\hline $\operatorname{Max}$ & 30.32 & 10.62 & 28.11 & 35.53 & 256.20 & 44.61 & 100.80 & 7.08 \\
\hline Mean & 3.78 & 2.08 & 5.34 & 7.85 & 76.20 & 21.01 & 36.55 & 4.39 \\
\hline Stdev & 8.37 & 2.74 & 7.23 & 10.55 & 58.44 & 12.80 & 21.19 & 2.06 \\
\hline
\end{tabular}

Generally, $\mathrm{Ca}$ and $\mathrm{Mg}$ maintain an equilibrium status in most of waters. Magnesium content is considered as one of the most important criteria for irrigation water assessment. Higher magnesium content in water affects plant production as soil becomes more saline. Crops yields are adversely affected with excess $\mathrm{Mg}^{2+}$ in water as the soil becomes more saline [27]. Water with MAR $<50 \%$ is suitable for irrigation while any one with MAR $>50 \%$ is not suitable for irrigation purposes [28]. Results from this research showed that only one (1) of the water samples has MAR $<50 \%$ while 11 have values above the permissible limit of $50 \%$. The water is unsuitable for irrigation based on MAR assessment. In Kelly's Ratio (KR), sodium is measured against calcium and magnesium to determine the suitability of irrigation water. When $\mathrm{KR}$ is $>1$, it indicates higher sodium and vice versa [16]. All water samples in this research have KR $>1$ and as such indicated that water from River Owan is not suitable for irrigation due to excess sodium in the water. From Table 3, except for MAR and $\mathrm{KR}$, water in the area is suitable for irrigation purposes. 
Table 5 gives the summary of the suitability of most irrigation parameters employed in this study. The Table clearly revealed that all employed parameters (SAR, RSBC, \%Na, TH, EC, TDS) confirmed that River Owan water is suitable for irrigation except MAR and KR that indicates otherwise. Non suitability as indicated by $\mathrm{KR}$ is a pointer to the fact that there is excess sodium which will invariably affect the soil composition. Potassium, magnesium, calcium, hydrogen and sodium which are the principle soil cations compete for available site on the clay and organic matter particles in the soil and with excess sodium, cations imbalance sets in. A situation that is not healthy for plant growth.

Table 3. Irrigation Index Parameters of Water samples from the Study Area

\begin{tabular}{|l|l|l|l|l|l|l|l|l|l|}
\hline Code & SAR & RSBC & MAR & KR & PS & SSP & \% Na & PI & Revelle Index \\
\hline O1 & 0.19 & 1.29 & 53.83 & 1.78 & 0.01 & 62.94 & 28.23 & 27.80 & 0.51 \\
\hline O2 & 0.15 & 0.95 & 61.79 & 2.19 & 0.05 & 55.75 & 35.66 & 41.67 & 0.35 \\
\hline O3 & 0.15 & 0.55 & 61.29 & 2.18 & 0.1 & 55.58 & 36.18 & 32.97 & 0.98 \\
\hline O4 & 0.16 & 0.95 & 61.79 & 2.35 & 0.23 & 59.17 & 35.33 & 40.38 & 0.59 \\
\hline O5 & 0.16 & 0.94 & 61.18 & 2.31 & 0.22 & 61.95 & 32.82 & 37.57 & 0.48 \\
\hline O6 & 0.16 & 0.95 & 63.71 & 2.49 & 0.24 & 57.2 & 37.36 & 41.04 & 0.47 \\
\hline O7 & 0.39 & 2.68 & 36.86 & 1.69 & 1.34 & 47.05 & 26.95 & 5.90 & 0.39 \\
\hline O8 & 0.2 & 0.88 & 65.08 & 2.15 & 0.19 & 70.33 & 19.93 & 17.18 & 0.34 \\
\hline O9 & 0.17 & 1.35 & 61.55 & 2.47 & 0.36 & 58.68 & 38.03 & 46.64 & 0.42 \\
\hline O10 & 0.18 & 0.72 & 60.9 & 2.19 & 0.22 & 57.92 & 34.04 & 25.31 & 0.59 \\
\hline O11 & 0.19 & 0.72 & 61.91 & 2.34 & 0.06 & 55.42 & 37.46 & 22.95 & 0.59 \\
\hline O12 & 0.16 & 0.74 & 61.41 & 2.31 & 0.16 & 55.61 & 37.97 & 33.44 & 0.59 \\
\hline Min & 0.15 & 0.55 & 36.86 & 1.69 & 0.01 & 47.05 & 19.93 & 5.90 & 0.34 \\
\hline Max & 0.39 & 2.68 & 65.08 & 2.49 & 1.34 & 70.33 & 38.03 & 46.64 & 0.98 \\
\hline Mean & 0.19 & 1.06 & 59.28 & 2.20 & 0.27 & 58.13 & 33.33 & 31.07 & 0.53 \\
\hline Stdev & 0.07 & 0.56 & 7.54 & 0.25 & 0.35 & 5.54 & 5.57 & 11.79 & 0.17 \\
\hline
\end{tabular}

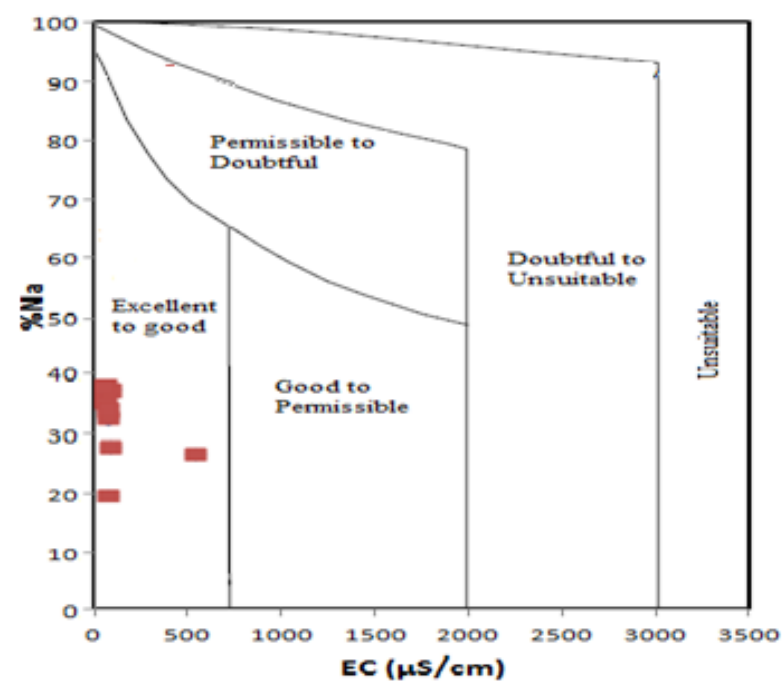

Figure 2. Rating of River Owan water samples on the basis of $\mathrm{EC}$ and $\% \mathrm{Na}[18]$

Table 4. Classification of groundwater for irrigation based on EC, SAR [19].

\begin{tabular}{|l|l|l|l|}
\hline Quality of water & EC $(\mu \mathrm{S} / \mathrm{cm})$ & SAR & Owan River Water \\
\hline Excellent & $<250$ & $<10$ & 11 samples (92\%) \\
\hline Good & $250-750$ & $10-18$ & 1 sample $(8 \%)$ \\
\hline Doubtful & $750-2250$ & $18-26$ & \\
\hline Unsuitable & $>2250$ & $>26$ & \\
\hline
\end{tabular}

Table 5. Irrigation Index characteristics of River Owan water

\begin{tabular}{|l|l|l|c|}
\hline Parameter & Range & Class & Samples (12) \\
\hline SAR & $0-10$ & Use for all soil types & All samples \\
{$[29]$} & $10-18$ & Preferably use on & \\
& $18-26$ & $\begin{array}{l}\text { coarse textured soil } \\
\text { May produce harmful } \\
\text { effect, good soil } \\
\text { management is } \\
\text { required } \\
\text { Unsatisfactory }\end{array}$ & \\
& $>26$ & \\
& & \\
\hline
\end{tabular}


Suitability Evaluation of River Owan Water for Irrigation

\begin{tabular}{|c|c|c|c|}
\hline $\begin{array}{l}\text { RSBC } \\
{[30]}\end{array}$ & $\begin{array}{l}<1.25 \\
1.25-2.5 \\
>2.5\end{array}$ & $\begin{array}{l}\text { Safe } \\
\text { Marginally suitable } \\
\text { Unsuitable }\end{array}$ & $\begin{array}{l}9 \\
2 \\
1 \\
\end{array}$ \\
\hline $\begin{array}{l}\% \mathrm{Na} \\
{[18]}\end{array}$ & $\begin{array}{l}<20 \\
20-40 \\
40-60 \\
60-80 \\
>80 \\
\end{array}$ & $\begin{array}{l}\text { Excellent } \\
\text { Good } \\
\text { Permissible } \\
\text { Doubtful } \\
\text { Unsuitable } \\
\end{array}$ & $\begin{array}{l}1 \\
11\end{array}$ \\
\hline $\begin{array}{l}\text { MAR } \\
{[31]}\end{array}$ & $\begin{array}{l}<50 \\
>50\end{array}$ & $\begin{array}{l}\text { Suitable } \\
\text { Unsuitable }\end{array}$ & $\begin{array}{l}1 \\
11\end{array}$ \\
\hline $\begin{array}{l}\text { TH } \\
{[32]}\end{array}$ & $\begin{array}{l}<75 \\
75-150 \\
150-300 \\
>300 \\
\end{array}$ & $\begin{array}{l}\text { Soft } \\
\text { Moderately } \\
\text { Hard } \\
\text { Very hard } \\
\end{array}$ & 12 \\
\hline $\begin{array}{l}\mathrm{KR} \\
{[33]} \\
\end{array}$ & $\begin{array}{l}<1 \\
>1 \\
\end{array}$ & $\begin{array}{l}\text { Suitable } \\
\text { Unsuitable }\end{array}$ & All samples \\
\hline $\begin{array}{l}\mathrm{EC} \\
{[32]}\end{array}$ & $\begin{array}{l}<250 \\
250-750 \\
750-2000 \\
2000-3000 \\
\end{array}$ & $\begin{array}{l}\text { Excellent } \\
\text { Good } \\
\text { Permissible } \\
\text { Doubtful } \\
\end{array}$ & $\begin{array}{l}11 \\
1\end{array}$ \\
\hline $\begin{array}{l}\text { TDS } \\
{[34]}\end{array}$ & $\begin{array}{l}<1000 \\
1000-3000 \\
3000-10000 \\
>10000\end{array}$ & $\begin{array}{l}\text { Non saline } \\
\text { Slightly saline } \\
\text { Moderately saline } \\
\text { Very saline }\end{array}$ & 12 \\
\hline
\end{tabular}

\section{Conclusion}

Irrigation assessment employing EC, Sodium Absorption Ratio (SAR), \% Na, Residual Sodium Bicarbonate (RSBC), Potential Salinity (PS) and Soluble Sodium Product (SSP) indicated that River Owan water was suitable for irrigation. However, Magnesium Adsorption Ratio (MAR) and Kelly Ratio (KR) showed non-suitability. The water is moderately suitable for irrigation and could serve as a buffer to farming activities especially during dry season in the area.

\section{References}

[1]. African Development Fund (ADB), Nigeria: Rural water supply and sanitation sub-programmes in Yobe and Osun States, appraisal report.Water and Sanitation Department (OWAS). May 2007.

[2]. P.A. Esoka, and J.M. Umaru, Industrial effluent and water pollution in Kakuri area, Kaduna South, Nigeria. Journal of Industrial pollution and control, 2006, Vol. 22, No 1, pp. 93-100. ISSN 0970-2083.

[3]. O.T. Adebayo, A.M. Balogun, and O.A. Olubiyi, Chemical analysis of some industrial effluents that discharge into Lagos Lagoon, Nigeria. Research Journal of Environmental Sciences, 2007, Vol. 1, No. 4, pp. 196-199. ISSN 1819-3412.

[4]. M.O. Jaji, O. Bamgbose, O.O. Odukoya, and T.A. Arowolo, Water quality assessment of Ogun River, South West Nigeria. Environmental Monitoring Assessment, 2007, Vol. 33, No 1-3, pp. 473-482. doi: 10.1007/s10661-006-9602-1. ISSN: 0167-6369

[5]. S.A. Mashi, and M.M. Alhassan, Effects of wastewater discharge on heavy metals pollution in Fadama soils in Kano City, Nigeria. [6] Journal of Biomedical and Environmental Sciences. 2007, Vol. 20, No 1, pp. 70-77.

[6]. Solomon, The state of solid waste management in Nigeria. Waste Management Journal, 2009, Vol. 29, No. 10, pp. 2787 - 2790.

[7]. A.M. Taiwo, Composting as a sustainable waste management technique in developing countries. Journal of Environmental Science and Technology, 2011, Vol. 4, No. 2, pp. 93-102. doi=jest.2011.93.102

[8]. F.O Arimoro, R.B. Ikomi, and E.C. Osalor, The impact of sawmill wood wastes on the water quality and fish communities of Benin River, Niger Delta Area, Nigeria. International Journal of Science and Technology. 2007, Vol. 2, No. 1, pp. 1- U.U. 12.web.firat.edu.tr/fenbilimleri/Dergiler/TJST/arsiv/.../1_\%20francis.pdf

[9]. A.O. Ogunfowokan, E.K. Okoh, A.A. Adenuga, and O.I. Asubiojo, An assessment of the impact of point source pollution from a university sewage treatment oxidation pond on a receiving stream - a preliminary study. Journal of Applied Sciences, 2005 Vol. 5 , No 1, pp. 36 - 43. Doi: 10.3923/jas.2005.36.43.

[10]. C.I. Ikhile, and G.U. Ikhile, Effects of climate change on irrigation activities: a case study of the Benin-Owena River basin irrigation projects. Water Resources Systems-Hydrological Risk, Management and Development (Proceedings of symposium IIS02b held during 1UGG2003 at Sapporo, July 2003). IAHS Publ. no. 281,

[11]. A.O. Talabi, F.O. Olufemi, C.A. Ajayi, O.A. Olaolorun, and O.L. Afolagboye, Hydrochemistry and Environmental Status of River Owan water,Edo State Nigeria. International Journal of Environment and Pollution Research Vol.4, No.5, pp. 1-15, December 2016

[12]. American Public Health Association, Standard Methods for the Examination of Water and Wastewater, 20th edition, 1998 Washington, DC. American Water Works Association and Water Pollution Control Federation.

[13]. L.A. Richards, Diagnosis and Improvement of Saline and Alkali Soils Agric. Handbook 60, USDA and IBH Pub. Coy Ltd., New Delhi, India, 1954, pp: 98-99.

[14]. L.N. Gupta, R. Avtar, P. Kumar, G.S. Gupta, R.L. Verma, N. Sahu, S. Sil, A. Jayaraman, K. Roychowdhury, E. Mutisya, K. Sharma, and S.K. Singh, A multivariate approach for water quality assessment of river Mandakini in Chitrakoot, India. Journal of Water Resource and Hydraulic Engineering, 2014, 3(1): 22-29.

[15]. I.I.M. Raghunath, Groundwater. Second edition; Wiley Eastern Ltd., New Delhi, India, 1987, 344 - 369.

[16]. W.P. Kelly, Use of saline irrigation water. Soil Sci., 1963, 95(4): 355-391.

[17]. I.D. Doneen, Notes on water quality in Agriculture. Published as water Science and Engineering. 1964. Paper 4001.Department of Water Sciences and Engineerring, University of California.

[18]. L.V. Wilcox, Classification and Use of Irrigation Waters. Department of Agriculture, United States, Circular No. 696, Washington D.C., 1950, pp: 16 . 
[19]. US Salinity Laboratory, "Diagnosis and improvement of saline and alkali soils", Agricultural Handbook 1954, No. 60. USDA, 160

[20]. A. Vasan, and K.S. Raju, Application of Differential Evolution for Irrigation Planning: An Indian Case Study. Water Resourses Management. 2007, Volume 21, Issue 8, pp 1393-1407.

[21]. N. Ahmed, M.A. Ali, M.K. Rashid, S. Noreen, and B. Butt, Irrigation quality of underground water in District Multan. Pak. J. Agri., Agril. Engg., Vet. Sci., 2015, 31 (2): 211-220

[22]. N. Aghazadeh, and A.A. Mogaddam, Assessment of Groundwater quality and its Suitability for Drinking and Agricultural Uses in the Oshnavieh Area, Northwest of Iran. Journal of Environmental Protection, 2010, 1: 30 - 40.

[23]. N.J. Raju, Hydrogeochemical parameters for assessment of groundwater quality in the upper Gunjanaeru River basin, Cuddapah District, Andhra Pradesh, India. Environmental Geology. 2006, 52(6): 1067-1074.

[24]. M.A. Hakim, A.S. Juraimi, M. Begum, M. Hasanuzzaman, M.K. Uddin, and M.M. Islam, Suitability evaluation of groundwater for irrigation, drinking and industrial purposes. Am. J. Environ. Sci., 2009, 5, 413-419.

[25]. S. Naseem, S. Hamza, and E. Bashur, Groundwater Geochemistry of Winder Agricultural Farms, Balochistan Pakistan and Assessment for Irrigation Water Quality. European Water, 2010, 31:21-32.

[26]. S.C. Nishanthiny, M. Thusshanthy, T. Barathithasan, and S. Saravanan, Irrigation water quality based on hydrochemical analysis, Jaffna, Sri Lanka. American-Eurasian journal of agriculture and environmental science, 2010, 7(1):100-102.

[27]. D.M. Joshi, A. Kumar, and N. Agrawal, Assessment of the Irrigation Water Quality of River Ganga in Haridwar District India. J. Chem. 2009, 2(2):285-292.

[28]. K.V. Paliwal, Irrigation with saline water, Monogram no. 2 (New series). New Delhi, IAR1, 1972, p198

[29]. S. Mandel, and Z.I. Shiftan, Groundwater Resources Investigation and Development, Academic Press, Inc.1991.

[30]. California Fertilizer Committee, Western Fertilizer Handbook. 5th Edn., The Interstate Printers and Publishers, Danville, Illinois, 1975,ISBN-13: 9780813417363 , pp: 250

[31]. R.S. Ayers, D.W. West cot, Water quality for Agriculture. FAO Irrigation and Drainage paper. 1985, Vol. 29 (1): pp. 1-174

[32]. M. Vasanthavigar, K. Srinivasamoorthy, K. Vijayaragavan, R. Rajiv, G.S. Chidambaram, P. Anandhan, R. Manivannan, and S. Vasudevan, Application of water quality index for groundwater quality assessment:Thirumanimuttar sub- basin, Tamilnadu, India, Environ Monit Assess , 2010, 171:595-609,

[33]. S.K. Sundaray, B.B. Nayak, and D. Bhatta, Environmental studies on river water quality with reference to suitability for agricultural purposes: Mahanadi river estuarine system, India- a case study. Environ. Monitor. Assess. 2009, 155:227-243.

[34]. C.J. Robinove, R.H. Longfort, J.W. Brook, Saline water resource of North Dakota US Geological Survey Water Supply Paper 1428. 1958. 